\title{
Riverbank Erosion, Population Migration and Rural Vulnerability in Bangladesh (A Case Study on Kazipur Upazila at Sirajgonj District)
}

\author{
Tanjinul Hoque Mollah ${ }^{1}$, Jannatul Ferdaush ${ }^{2, *}$ \\ ${ }^{1}$ Department of Geography and Environment, Jahangirnagar University, Bangladesh \\ ${ }^{2}$ Department of Urban Studies and Planning, Savannah State University, GA, USA
}

Copyright (C) 2015 by authors, all rights reserved. Authors agree that this article remains permanently open access under the terms of the Creative Commons Attribution License 4.0 International License

\begin{abstract}
This paper aims at identify the number of climate induced migrants in kazipur upazila with specific reference to riverbank erosion. The study has used Kazipur upazila of Sirajganj for riverbank erosion, which is already identified as the most erosion prone area in Bangladesh. People affected by river bank erosion and immediately migrate for safe shelter and later permanently for survival, are examples of practical risk. While people migrate based on the perception that in future there would be worse condition that could hamper lives and livelihood; the adverse effect of rise of riverbank erosion compels the population to migrate from one place to another. In the Kazipur upazila of Sirajganj district, 21,961 people were migrated which is 9.35 percent of the total population in recent years [1]. The precise cause of riverbank erosion in Bangladesh there are $1,29,853$ people are displaced yearly [2]. Permanent migration occurred within the neighbors and mainly it happened in a tiny distance because of the need of earning source and social bonding. In this paper we have considered observed risk such as river bank erosion as causal factors of migration and rural vulnerability, which has important socio-economic impact on rural development.
\end{abstract}

Keywords Migration, Riverbank Erosion, Rural Vulnerability and Climate Change

\section{Introduction}

Riverbank erosion is a destructive hazard in Bangladesh that permanently displaces and impoverishes people. The Jamuna River flo od pla in covers most of the northern portion of Bangladesh. Forceful Jamuna River's local channels have intermittently and impulsively wandered across the land, erode banks, destroyed everything in their paths and accreting land elsewhere. River Bank erosion is common place both there and on other floodplain of the country. Irregular flooding and fast riverbank shifts seriously disrupt human settlement and activities. This study demonstrates the extent of the riverbank erosion by examining its occurrences in an area of the Jamuna river floodplain and determining number of population displaced.

Rivers are dynamic systems as they are continuously changing their way. In its natural process, erosion and accrual is normal. Though, sometimes erosion exceeds accretion and cause havoc in lives and livelihoods, mostly the poor society become the worst casualty. Riverbank erosion occurs both naturally and through human interference. The natural riverbank erosion process can produce favorable outcomes such as the formation of productive floodplains and alluvial terraces. Even stable rivers may have some amount of erosion; however, unstable rivers and the erosion that take place beyond normal range on either bank is a serious concern. Environmental refugees are one of the most burning issues at this time all over the world. Bangladesh, a riverine country, is suffering from acquit riverbank erosion which compels millions of her population to be displaced from their place of origin. As such, 283 locations, 85 towns and growth centers, along with 2400 kilometers of riverbank line in Bangladesh are vulnerable to erosion [3].

\subsection{Migration for Riverbank Erosion}

Migration phenomenon occupies a significant part of human history that started since the dawn of civilization in search of food, shelter or civilizing living condition. Though, either forced or Otherwise, human migration is the most significant consequence of climate change of today and coming decades [4]. Environmental degradation and climate change could potentially result in large scale population migration where the world is presently ill-equipped to prevent or address in an effective method. Both the climatic and non-climatic drivers are causal to growing mass of migrants worldwide. In case of climate drivers, climate processes such as sea-level rise, salinization of farming land, 
desertification and growing water lack, and climate events such as flooding, storms etc are forcing man to migrate. But government policy a non-climate drivers, such as, population growth and community-level resilience to natural disaster, are also important [4]. However, the speed of migration and number of migrated people depend on severity of the disasters and social and economic strength of addressing the disasters of the respective areas.

\subsection{Climate Change and Rural Vulnerability}

Bangladesh is one of the most disaster prone countries of the world. Despite progress in economy the country has been struggling to maintain the growth due to recurring natural disasters. Whenever the country hits the headlines of the world press and the other media, some natural or man-made calamities occupy the centre of attention, playing havoc with human lives, crops, cattle raising, poultry, fishery, houses, roads, forests and many other types of property and economic infrastructure. In this paper, we shall focus on the climate induced migration in Bangladesh, who has been uprooted from their homes by due to natural disasters floods, salinization, droughts and river erosions where a combination of economic, social, institutional and political factors catalyzes the process. Migration occurs both temporarily and permanently. Temporary migration as an adaptive response to climate stress is already apparent in many areas. But the image is nuanced; the talent to migrate is a function of mobility and resources (both fiscal and social). In other words, the people most helpless to climate change are not necessarily the ones most likely to migrate [3]. On the other hand permanent migration occurs when the people lose all other alternatives to survive in one area; for instance loss of land and settlements due to tidal surge and river erosions. About each year, a major number of populations is displaced or forced to migrate both temporarily and permanently, due to natural calamities in Bangladesh. Approximately 500,000 people were displaced when the Bhola Island was permanently inundated by the floods of 2005 [5]. In addition, recent occurrences of major cyclones like Sidr, 2007, and Aila, 2009, may be a warning of more frequent and severe climatic catastrophe. But, there is still a lack of awareness among the public about climate change and also, little consensus among the concerned bodies about the existence and the types of environmental effects of climate change and the numbers of environmental displacements [6].

\section{Objectives, Sources of Data and Methodology}

The research aims to quantify internal migrants forced by factors derived from riverbank erosion. To fulfill the aim of the research the following specific objectives have been place up. Those are:

1. To explore migration occur due to riverbank erosion with the support of local people perception.

2. Problem identification within the areas and counting the rate of migration, mapping and analyzing the current and future scenario of riverbank erosion vulnerability of the study area.

The study used primary data and secondary source to meet up the objectives of the study. The study mainly depends upon primary data which has been done through FGD, key informants Interview, case study and personal observation.

Secondary data such as census, Google earth image, Districts Maps, Upazila and Union Maps were used for detailed analysis of the migration and displacement. The secondary data and literature helps to identify the each vulnerable area such as riverbank erosion and in the different regions of Bangladesh. There are some methods for counting the number of people exposed to riverbank erosion. The following equation expresses the people displaced due to riverbank erosion.

$\sum$ Displaced population $=\left\{\left(\sum\right.\right.$ Population $/$ Area $) * \sum$ eroded area\}

\section{Limitations of the Study}

1. Facing problems in conducting field survey: It is one of main factors to make the study enriched. Detail land use information is a vital element for land use survey. Various problems were faced in conducting field survey while collecting primary data from flat resident and renters, which are not mentioned here.

2. Lack of co- ordination and conflicting responsibility: While collecting secondary data from various housing builders' office, there were found lack of coordination and they are not obeying their duty and responsibility properly. In simple word they are not agree for proving real information and trying to conflicting their responsibility.

3. Manpower limitation: The sample size selected for the questionnaire survey to analysis the perception of flat residents about their community service and facilities and their demands. Analysis on a bigger size can ensure better result which is not possible for time and manpower limitations.

\section{Study Area}

\subsection{Riverbank Erosion of Kazipur Upazila of Sirajganj District}

Kazipur Upazila is located between $24^{\circ} 38^{\prime} 30^{\prime \prime}$ and $24^{\circ} 64^{\prime} 17^{\prime \prime}$ north latitudes and between $89^{\circ} 39^{\prime} 00^{\prime \prime}$ and $89^{\circ} 65^{\prime} 00^{\prime \prime}$ east longitudes. Kazipur Upazila is $368.63 \mathrm{sq} \mathrm{km}$ and it is surrounded by Dhunat, Sariakandi and Sarishabari Upazilas and the Jamuna River on the north, Sirajganj Sadar Upazila on the south, Sarishabari Upazila and the Jamuna River on the east, Dhunat Upazila on the west $[7,10]$. There 
are several inhabitation including Mallickpara, Dhulaura, Maijbari, Manik Patal, Kazipur, Meghai, Tarakandi, erosion. Jamuna-Bhramaputra Flood Protection Dam built in Tengalahata are regularly getting extinct by riverbank the 1960 on the west side of the Jamuna could help much neither in defy river erosion nor in controlling flood.

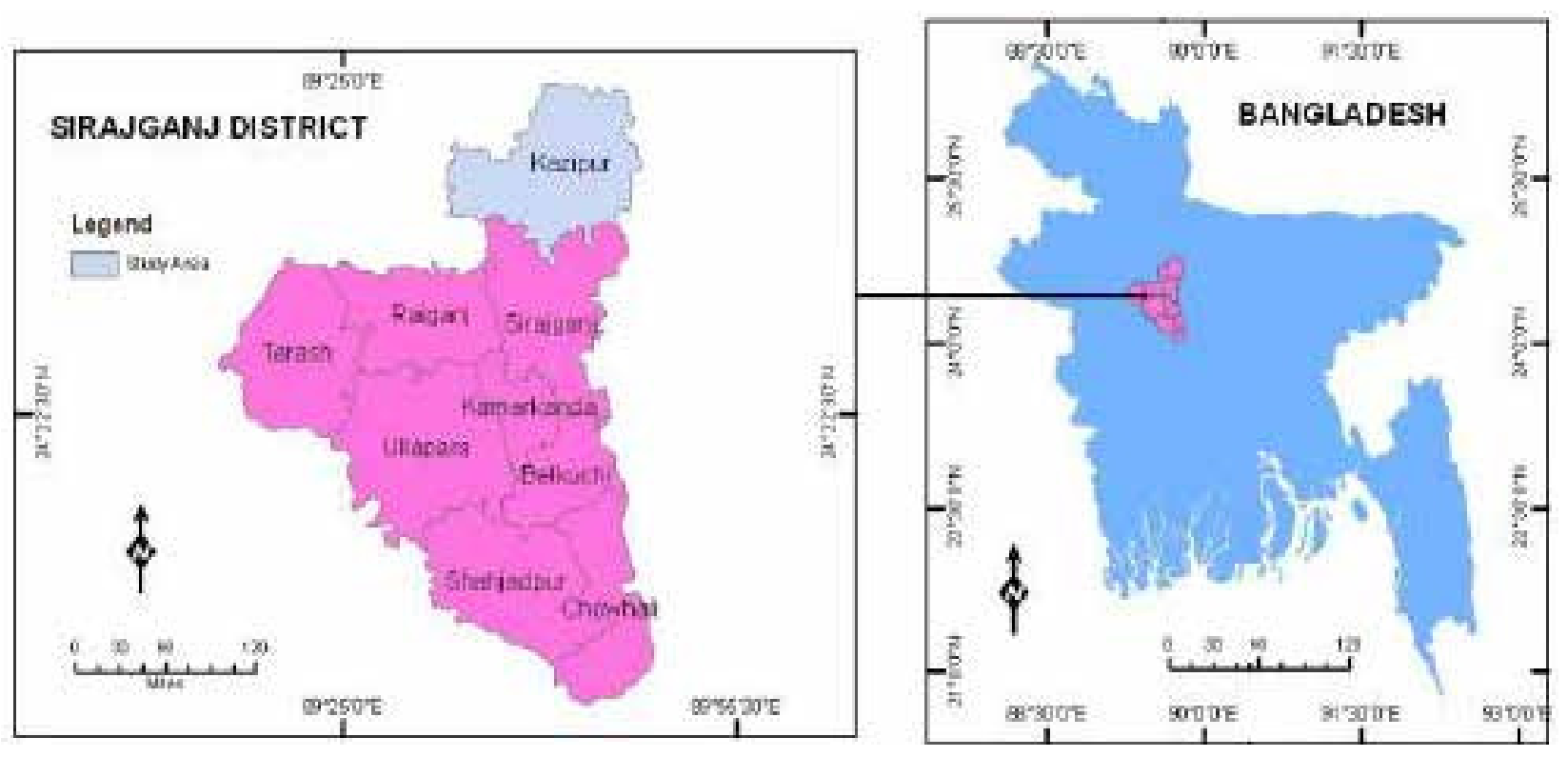

Figure 1. Map of the Study Area

RIVER BANK EROSION AND MIGRATION Tasipur Upazla, Banglodecth
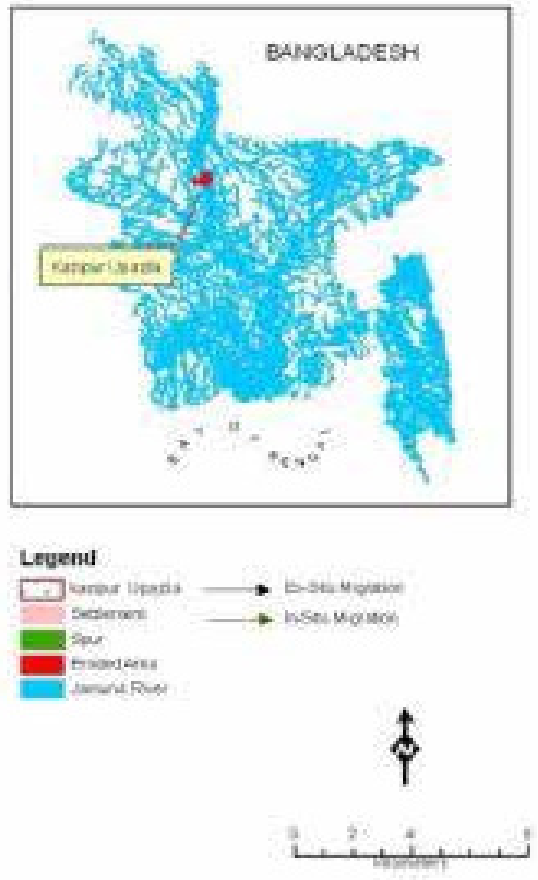

Figure 2. Recent scenario of Eroded area, In-Situ and Ex-Situ Migration 


\section{Major Findings of the Study}

This study was conducted to explore the existing situation of riverbank erosion, what type of migration occurs and socio-economic impact of this type of natural disaster.

\subsection{Recent Scenario of Eroded Area, In-situ and Ex-situ Migration}

Kazipur Upazila is facing extensive riverbank erosion and consequent environmentally forced migration. Displacement due to river bank erosion in Kazipur Upazila of Sirajganj district is at increasing trend over the years that cause both in-situ and ex-situ migration . In case of in-situ migration, a significant amount of displaced people are forced to live in embankments. Erosion mainly depends on land slope where convex slope is more prone to erosion than the concave slope [6]. The studied area seems to have convex slope that is subject to widespread erosion (Figure 2). Being located at the upstream of Jamuna River, Kazipur faces high speed of the wave action which destroys the slope of the land.

According to Table 1 and Figure 3, the eroded area is about $34.43 \mathrm{Sq}$ in the recent year, 2011. As per as to the local people perception, if there is no construction of embankment surroundings the vulnerable areas it will be submerged within one or two years [1]. In the above table it is clearly understood that river bank erosion is one of the major causes for migration. The rate of riverbank erosion is high in the Khas Rajbari Union, Meghai and Maijbari Union. In the recent year 2011, $34.43 \mathrm{sq} \mathrm{km}$ area was eroded and its percentage to total land was around $9.35 \%$ [1].

Table 1. Land features of Kazipur Upazila, Sirajganj

\begin{tabular}{|c|c|c|c|c|}
\hline & Area in Hectares & $\begin{array}{c}\text { Area in sq } \\
\mathrm{km}\end{array}$ & $\begin{array}{c}\text { Total Area } \\
\text { in sq km }\end{array}$ & Percentage (\%) \\
\hline Settlement & 2720 & 27.20 & & 7.39 \\
\cline { 1 - 2 } $\begin{array}{c}\text { Agricultural } \\
\text { Land }\end{array}$ & 22708 & 227.08 & \multirow{2}{*}{368.12} & 61.69 \\
\cline { 1 - 2 } \cline { 5 - 5 } River & 7941 & 79.41 & & 21.57 \\
\hline Eroded area & 3443 & 34.43 & & 100 \\
\hline \multicolumn{3}{|c|}{ Total } \\
\hline
\end{tabular}

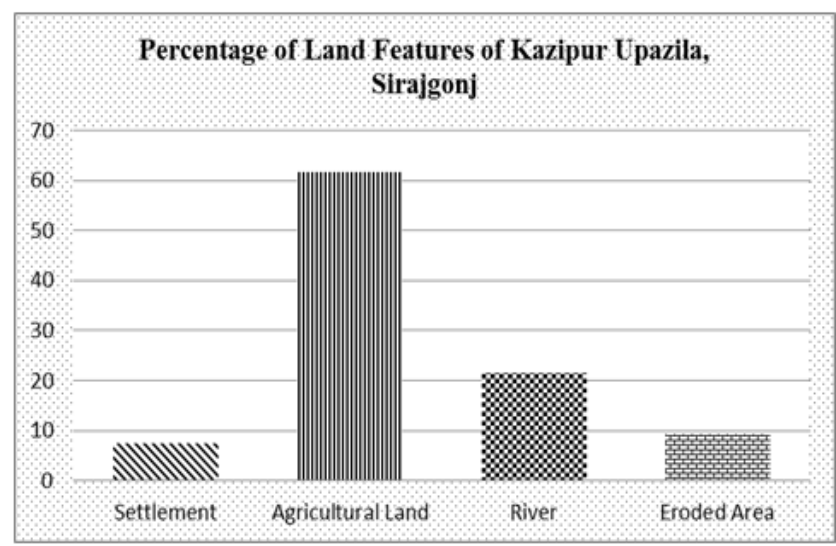

Figure 3. Percentage of Land Features of Kazipur Upazila, Sirajgonj

\subsection{Migration Due to Riverbank Erosion in Kazipur Upazila}

In-situ migration is more than ex-situ migration because of continuous erosion and deposition of char land in usual process. As an effect, the local people of the char land area have migrated to nearer char land which was newly created. Due to river bank erosion, the rate of forced migration is estimated as $9.35 \%$ in 2011 which corresponds to 21,961 people [1].

Table 2. Migration due to riverbank erosion in Kazipur Upazila (percentage)

\begin{tabular}{|c|c|c|c|}
\hline Total Population & $\begin{array}{c}\text { Population } \\
\text { Density }\end{array}$ & $\begin{array}{c}\text { Migrated } \\
\text { Population }\end{array}$ & Percentage (\%) \\
\hline $2,34,804$ & 637 & 21,961 & 9.35 \\
\hline
\end{tabular}

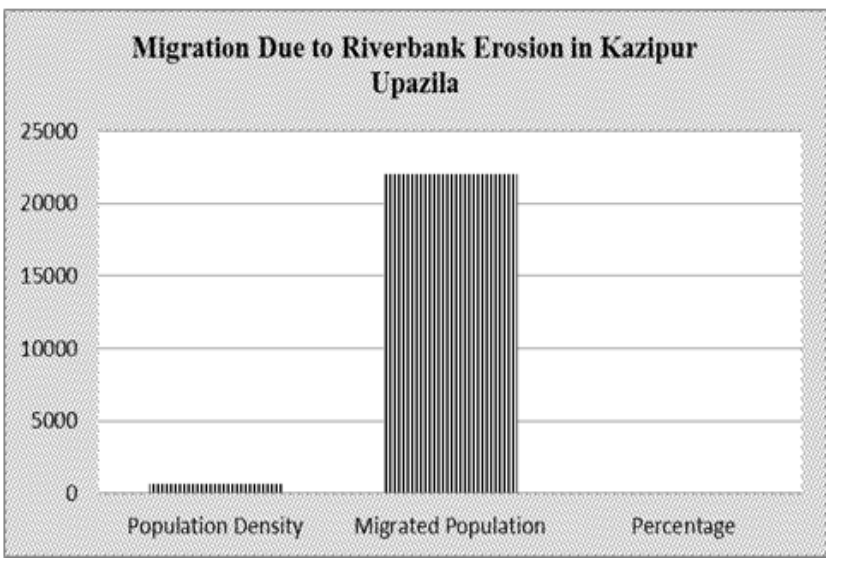

Figure 4. Migration Due to Riverbank Erosion in Kazipur Upazila

The column graph in figure 4 compares the percentage of migration due to riverbank erosion in Kazipur Upazila. According to figure 4, the total population of Kazipur Upazila is about 2, 34,804; approximately 637 are about population density of the study area. By the other side percentage of migrated population is about $9.35 \%$. The information given in the column graph does not give the reasons for this type of migration data, yet it would be important for any climate change or migration related research to apply any experiment with adjusting this type of region level.

\subsection{Future Scenario of Riverbank Erosion and Flood in Kazipur Upazila}

Natural disaster such as flood usually characterized by a rapid onset, and its destructive impact are function of the number of vulnerable people in the region rather than the severity of the disaster. Poor people in the Kazipur Upazila are the most affected because they are the most vulnerable. Recent flooding in the Kazipur Upazila forced numbers of people to be displaced from their origin. 


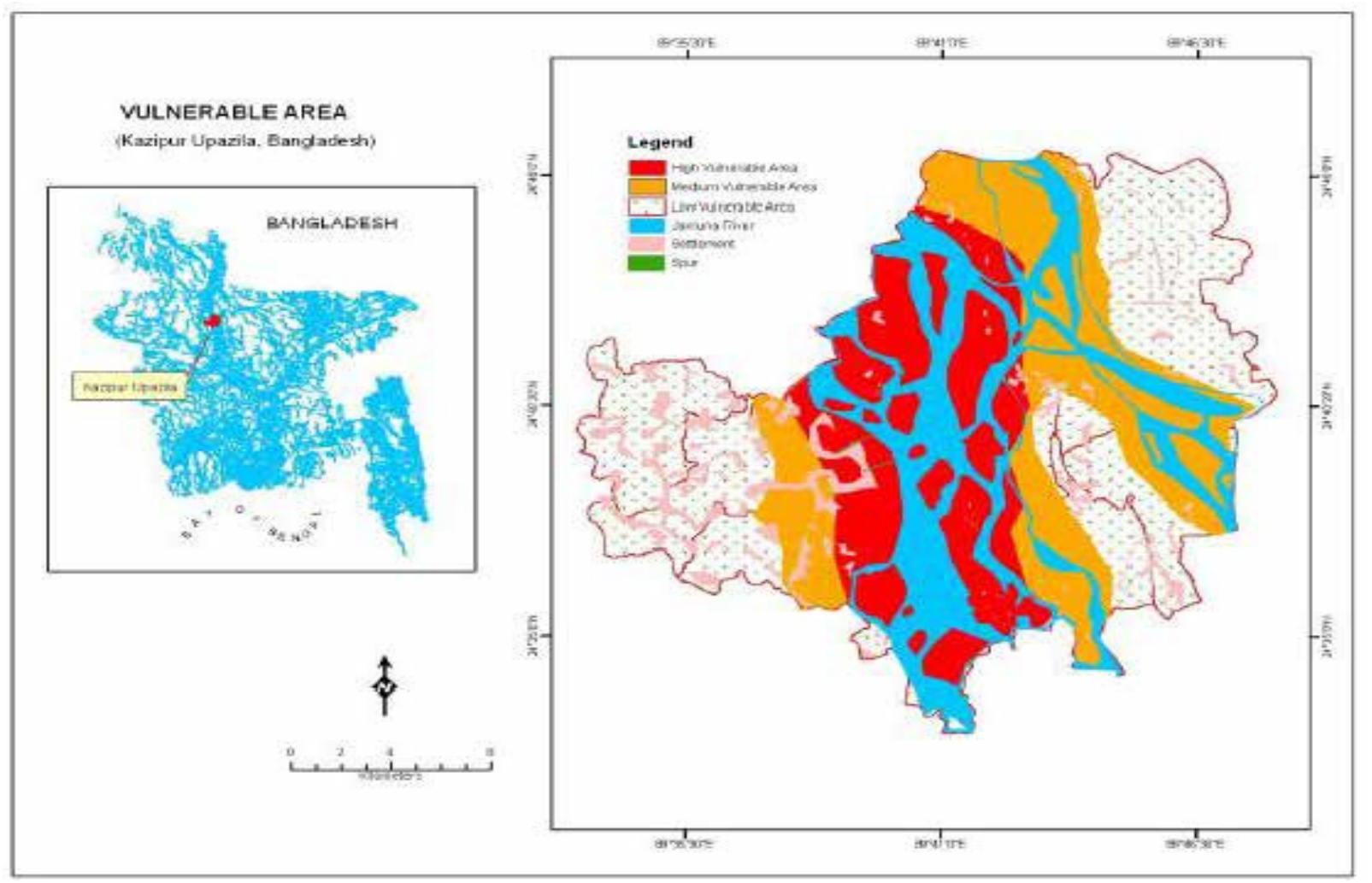

Figure 5. Vulnerability map of the Kazipur Upazila

If riverbank erosion continues in the Kazipur Upazila the rate of migration will increase gradually. Total Kazipur Upazila is divided into three major categories according to the vulnerability. The no. one is greatly vulnerable area which consists $47.01 \mathrm{Sq} \mathrm{km}$; the second one is medium vulnerable area which consists $106.56 \mathrm{Sq} \mathrm{km}$ and the final one is low vulnerable area which consists $134.93 \mathrm{Sq} \mathrm{km}$ of the total of the Kazipur Upazila. Upward areas are more prone to erosion than downward areas because in the upward areas the velocity of the wave is high.

Table 3. Vulnerable areas (\%) in Kazipur Upazila

\begin{tabular}{|c|c|c|c|c|}
\hline & $\begin{array}{c}\text { Area in } \\
\text { Hectares }\end{array}$ & $\begin{array}{c}\text { Area in sq } \\
\mathrm{km}\end{array}$ & $\begin{array}{c}\text { Total Area in sq } \\
\mathrm{km}\end{array}$ & $\begin{array}{c}\text { Percentage } \\
(\%)\end{array}$ \\
\hline $\begin{array}{c}\text { High } \\
\text { Vulnerable } \\
\text { Area }\end{array}$ & 4701 & 47.01 & & 12.77 \\
\hline $\begin{array}{c}\text { Medium } \\
\text { Vulnerable } \\
\text { Area }\end{array}$ & 10656 & 106.56 & 368.12 & 28.95 \\
\hline $\begin{array}{c}\text { Lulnerable } \\
\text { Area }\end{array}$ & 13493 & 134.93 & & \\
\cline { 1 - 2 } & & & & \\
\hline
\end{tabular}

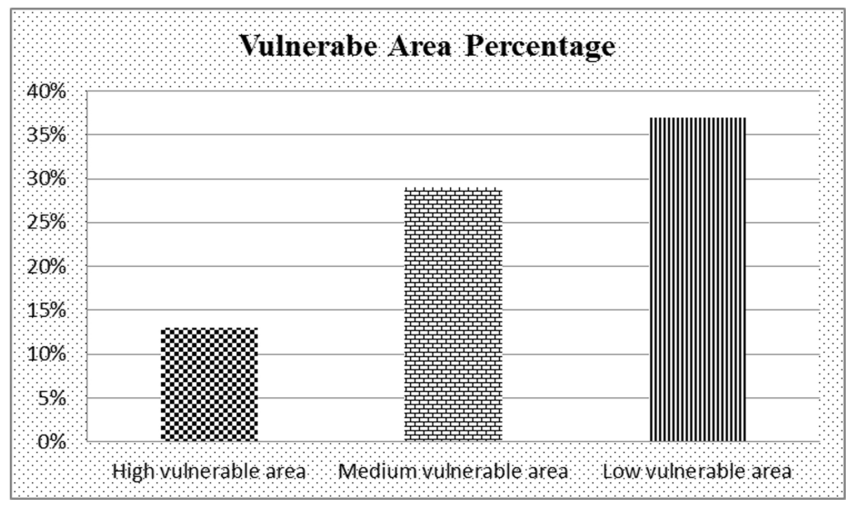

Figure 6. Vulnerable area shown in a Bar chart

The bar chart shows the approximate vulnerable area of the Kazipur Upazila in Sirajganj district based on field survey 2011 while conducting the research.

\subsection{Migrated Population in Future of the Kazipur Upazila}

Total population of the Kazipur Upazila is 2, 34,804 and if it relics fixed in future the rate of forced migration due to riverbank erosion is $12.75 \%$ years [7]. In the char land permanent migration varies occasionally because of continuous formation of char land. Lesser amount of the population migrates because of education. 
Table 4. Migrated population in future of the Kazipur Upazila

\begin{tabular}{|c|c|c|c|}
\hline $\begin{array}{c}\text { Total } \\
\text { Population }\end{array}$ & $\begin{array}{c}\text { Population } \\
\text { Density }\end{array}$ & $\begin{array}{c}\text { Future Migrated } \\
\text { Population }\end{array}$ & $\begin{array}{c}\text { Percentage } \\
(\%)\end{array}$ \\
\hline $2,34,804$ & 637 & 29,945 & 12.75 \\
\hline
\end{tabular}

\subsection{Overall Scenario of Riverbank Erosion and Displacement in the Perspective of Bangladesh}

The population density in Bangladesh is reported to be 1263.16 per sq $\mathrm{km}$ in 2010 [8]. Population density in three different regions of Bangladesh depends upon the total number of population and the sum area. In 2011, $34.43 \mathrm{Sq}$ $\mathrm{km}$ have been eroded in the Kazipur upazila of Sirajganj district years [1]. If compared to the national set-up, then the total eroded area in Bangladesh due to riverbank erosion is 10280 hectares or $102.80 \mathrm{sq} \mathrm{km}$ years [2]. The rate of forced migration due to riverbank erosion in the Kazipur upazila of Sirajganj district is 9.35 percent in 2011. If the riverbank erosion occurs accordingly to the year of 1984-93, the number of displaced population is 1, 29,853 in the Jamuna, Ganges, Padma and Meghna River in the current year. Riverbank erosion and accretion in the different floodplain are common and natural processes [9]. The people of Bangladesh cope with this situation as because it is itself a natural process (figure 7).

Table 5. Bank erosion/accretion along the different rivers for the period of 1984-92

\begin{tabular}{|c|c|c|c|c|c|c|}
\hline \multicolumn{2}{|c|}{} & Jamuna & Ganges & Padma & $\begin{array}{c}\text { Upper } \\
\text { Meghna }\end{array}$ & $\begin{array}{c}\text { Lower } \\
\text { Meghna }\end{array}$ \\
\hline $\begin{array}{c}\text { Bank } \\
\text { erosion } \\
\text { rate (m/yr) }\end{array}$ & Left & $* 100$ & -20 & 38 & 7 & 66 \\
\hline $\begin{array}{c}\text { Maximum } \\
\text { erosion rate (m/yr) }\end{array}$ & $* 84$ & 56 & 121 & -9 & 182 \\
\hline $\begin{array}{c}\text { Bank erosion } \\
\text { (ha/yr) }\end{array}$ & 5020 & 2240 & 1800 & 48 & 1172 \\
\hline
\end{tabular}

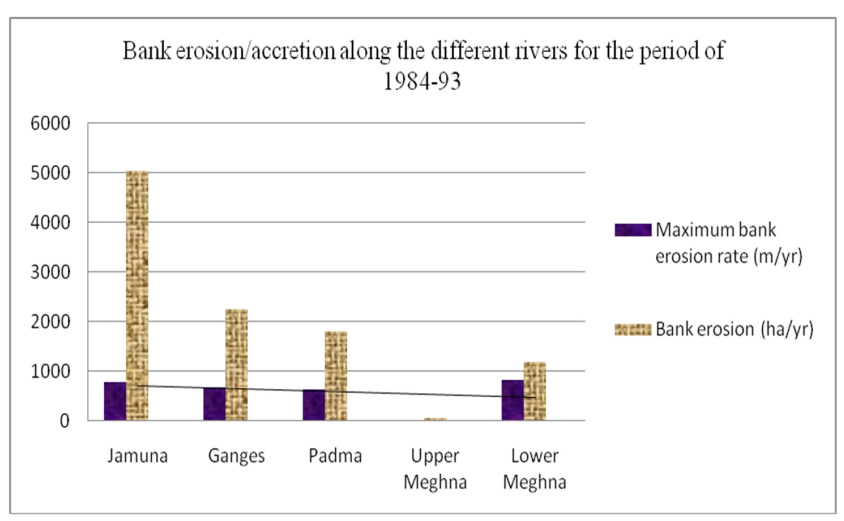

Figure 7. Riverbank Erosion Trend (1984-92) of various rivers from bureaucratic dictatorial society.

\section{Recommendations}

- Various coping techniques and survival strategies have to be adopted to recover the gains and losses of riverbank erosion. It might be short term or long term basis. Sort term in the sense that various post disaster help of all types like giving relief materials, storing reserves of food and seeds, immediate needs as pure water, food, medicine and long term in the sense that during the distress period credit facilities play as the most important role for their survival strategies. Ownership of land is the pre-condition of getting loan facilities or some permanent assets or address. As an effect so they do not get any access to loan and suffering much. For recovering rural vulnerability and long term rural development it is urgent to assure proper occupational facilities after the distress period.

- Already 21,961 populations displaced which is $9.35 \%$ of the total population years [1]. Next year (2012) it is likely to be $12.375 \%$ of the total population. So Community Based Techniques (CBT) should be ensured to cope out from the devastating effects of riverbank erosion. For that reason they have to learn that why they are helpless and why they would not surrender to fate. Traditional Crop Cultivation Structures and Building Structures should be changed to adopt with climatic change.

- During 2011, $34.43 \mathrm{sq} \mathrm{km}$ area has been eroded and it was $9.35 \%$ of the total land area of the Kazipur upazila years [6]. In future, the eroded area will be increased because of unplanned structure and lack of planning. 47.01 Sq km area will be highly vulnerable to riverbank erosion in recent future. Government should adopt National Territory Policy to ensure the territory of disaster affected people. A Digital Database System of Disaster (DDSD) is urgent to be developed by the government to explore the sequence of riverbank erosion, magnitude of riverbank erosion and its effects on sustainable rural development.

- Various political land owning classes misuse the power structure and determine to get the re-emerged land from the riverbeds. Local authority has to be accountable and transparent to give the claims and disputes the emerged land.

- Newly accreted land takes up to 12 to 15 years to get full production potentials naturally for agricultural purposes [5]. For that reason government should take necessary steps for taking various experiments for making the recovering time short and remove the suffering of distress people.

- Property Relocation Strategy (PRS) and floodplain zoning would be important long term strategy to solve the problem of disaster affected people and as per as need institutional response and policy intervention

\section{Conclusions}

Wrestling with force of nature is illogical but with the 
consequences of natural disaster is our human ethics. Rural poor people remain poor and losing their all properties with a recurrent timeline. They also suffer a lot vulnerable situation for their land displacement. Moreover various strategies aimed at reducing extreme vulnerabilities of riverbank erosion might be seed selection, planting regimes, emergency awareness, apposite land use management and disaster attentiveness. Local authority should have special budgetary allocation for mobilizing community resources, improving rural livelihood and ensuring sustainable rural development.

\section{REFERENCES}

[1] FIELD SURVEY, 2011.

[2] MOLLAH. T. H ET. AL. Accounting Climate Induced Migration in Bangladesh: An Exploratory GIS Based Study, Unnayan Onneshan-the Innovators, Dhaka, Bangladesh, 2011.

[3] ISLAM F. MD. AND RASHID A.N.M. BASLUR, Riverbank erosion displacees in Bangladesh: need for institutional response and policy intervention, Bangladesh Journal of
Bioethics, Vol 2, No 2, Dhaka, Bangladesh, 2011.

[4] BROWN, O, Migration and Climate Change, International Organizations for Migration, Geneva, Switzerland, 2008.

[5] SAIFUZZAMAN, MD. AND ALAM MD. S. Erosion Induced Hazard Assessment of the Brahmaputra (Jamuna) River Floodplain Using Remote Sensing and GIS Data. Dhaka: Center for Environmental and Geographic Information Services (CEGIS) and Department of Geography and Environment, Jahangirnagar University, 2008.

[6] MIGRATION REVIEW, Issue 31, Refugee Studies Centre, University of Oxford, UK.

[7] UDDIN, MUHAMMAD ALA, Displacement and Destruction of Ethnic People in Bangladesh, Canadian Social Science, 2008.

[8] ASIAN DEVELOPMENT BANK Grant assistance, People's Republic of Bangladesh: social development for erosion-affected poor in the Jamuna-Meghna floodplains (financed by the Japan Fund for Poverty Reduction). Manila: Asian Development Bank, 2005.

[9] ISPAN IRRIGATION SUPPORT PROJECT FOR ASIA AND THE NEAR EAST, Newsletter No. 25, 1992.

[10] UDDIN A.F.M AZIM \& BASAK J.K., Effects of Riverbank Erosion on Livelihood, Unnayan Onneshan-the Innovators, Dhaka, Bangladesh, 2011 